\section{Adjustment of Mineral Elements in the Culture Medium for the Micropropagation of Three Vriesea Bromeliads from the Brazilian Atlantic Forest: The Importance of Calcium}

\author{
Alice Noemí Aranda-Peres \\ Universidade de São Paulo (USP), Centro de Energia Nuclear na \\ Agricultura (CENA), Av. Centenário 303, Piracicaba, SP, 13400-970, Brazil
}

\section{Lázaro Eustáquio Pereira Peres}

Universidade de São Paulo (USP), Escola Superior de Agricultura "Luiz de Queiroz" (ESALQ), Av. Pádua Dias 11, Piracicaba, SP, 13418-970, Brazil

\author{
Edson Namita Higashi ${ }^{1}$ \\ Universidade de São Paulo (USP), Escola Superior de Agricultura "Luiz de \\ Queiroz" (ESALQ), Av. Pádua Dias 11, Piracicaba, SP, 13418-970, Brazil
}

\author{
Adriana Pinheiro Martinelli \\ Universidade de São Paulo (USP), Centro de Energia Nuclear na Agricultura \\ (CENA), Av. Centenário 303, Piracicaba, SP, 13400-970, Brazil
}

Additional index words. in vitro culture, in vitro nutrition, leaf mineral analysis, Vriesea friburguensis, Vriesea hieroglyphica, Vriesea unilateralis

\begin{abstract}
Many different species of Bromeliaceae are endangered and their conservation requires specific knowledge of their growth habits and propagation. In vitro culture of bromeliads is an important method for efficient clonal propagation and in vitro seed germination can be used to maintain genetic variability. The present work aims to evaluate the in vitro growth and nutrient concentration in leaves of the epiphyte bromeliads Vriesea friburguensis Mez, Vriesea hieroglyphica (Carrière) E. Morren, and Vriesea unilateralis Mez, which exhibit slow rates of growth in vivo and in vitro. Initially, we compared the endogenous mineral composition of bromeliad plantlets grown in half-strength Murashige and Skoog (MS) medium and the mineral composition considered adequate in the literature. This approach suggested that calcium (Ca) is a critical nutrient and this was considered for new media formulation. Three new culture media were defined in which the main changes to half-strength MS medium were an increase in Ca, magnesium, sulfur, copper, and chloride and a decrease in iron, maintaining the nitrate:ammonium rate at $\approx 2: 1$. The main difference among the three new media formulated was Ca concentration, which varied from $1.5 \mathrm{~mm}$ in half-strength MS to 3.0, 6.0, and $12 \mathrm{~mm}$ in M2, M3, and M4 media, respectively. Consistently, all three species exhibited significantly higher fresh and dry weight on M4, the newly defined medium with the highest level of Ca (12 mM). Leaf nitrogen, potassium, zinc, magnesium, and boron concentrations increased as $\mathrm{Ca}$ concentration in the medium increased from 1.5 to $12 \mathrm{~mm}$.
\end{abstract}

Bromeliaceae are known for their diverse forms, which range from soil-rooted terrestrials to epiphytes, which rely on their "tanks" and/or absorptive trichomes for water and nutrient absorption (Crayn et al., 2004). Epiphytic bromeliads are commonly well adapted to arid environments not only as a result of morphological modifications, but also for the presence of the crassulacean acid metabolism (CAM), a photosynthesis adaptation common in many Bromeliaceae. Although CAM photosynthesis improves water use efficiency as a result of limited water vapor exchange with the atmosphere during the day (Crayn et al., 2004), the limitation of $\mathrm{CO}_{2}$ capture only during the nighttime results in slower plant growth rates (Cushman and Bohnert, 1999). This type of metabolism has important implications for the mineral nutrition of these species. In addition, nutrient absorption in "atmospheric" (e.g., Tillandsia spp.) or in "tank" bromeliads (e.g., Aechmea spp. and Vriesea spp.) frequently occurs in the organic form by absorptive leaf trichomes, making the process of mineral nutrition in bromeliads unique (Benzing, 1990). These specificities related to growth and nutrient absorption of bromeliads have raised interest in the use of specific culture conditions for bromeliad micropropagation (Endres and Mercier, 2001; Hosoki and Asahira, 1980; Nievola et al., 2001) and have been the subject of a growing number of studies on different ornamental bromeliad genera such as Guzmania (Lin and Yeh, 2008), Noeregelia (Carneiro et al., 1999), Dyckia (Pompelli and Guerra, 2005), Cryptanthus (Carneiro et al., 1998; Mathew and Rao, 1982), Tillandsia (Pickens et al., 2000, 2003, 2006), and Vriesea (Alves et al., 2006; Mercier and Kerbauy, 1992, Rech Filho et al., 2005)

In addition to factors that influence in vitro growth such as plant growth regulators, temperature, and light quality, mineral nutrition plays an important role (Morard and Henry, 1998; Niedz and Evens, 2007). For an efficient micropropagation process, it should be noted that the ideal mineral composition of the culture medium may vary considerably with each species or genotype (Gonçalves et al., 2005; Williams, 1991). Although there are many reports on medium optimization, growth regulator type and concentration are the most frequent objects of study. In contrast, little has been done in terms of in vitro mineral nutrition, especially for nonconventional species (Morard and Henry, 1998) such as bromeliads (Endres and Mercier, 2001; Nievola et al., 2001). Only recently, as mentioned by Niedz and Evens (2007), have a number of different approaches been used by researchers attempting to define the adequate balance of mineral nutrients with positive results. The availability of new media formulation for different species is important for a better response in vitro and has not yet been attempted for bromeliads.

Designing culture media according to the specific mineral composition of the plant tissues has been reported mainly with perennials such as olive (Cozza et al., 1997), passion fruit (Monteiro et al., 2000), eucalypt (Gribble et al., 2002), hazelnuts (Nas and Read, 2004), pear (Sotiropoulos et al., 2006), and apple (Sotiropoulos, 2007). However, the most common medium, used in $50 \%$ to $75 \%$ of the micropropagated plants, is still Murashige and Skoog (MS) medium (Murashige and Skoog, 1962), which was formulated for tobacco callus cultures (Gribble et al., 2002). The interaction among mineral elements creates challenges for the definition of new culture media (Nas and Read, 2004, Niedz and Evens, 2007). 

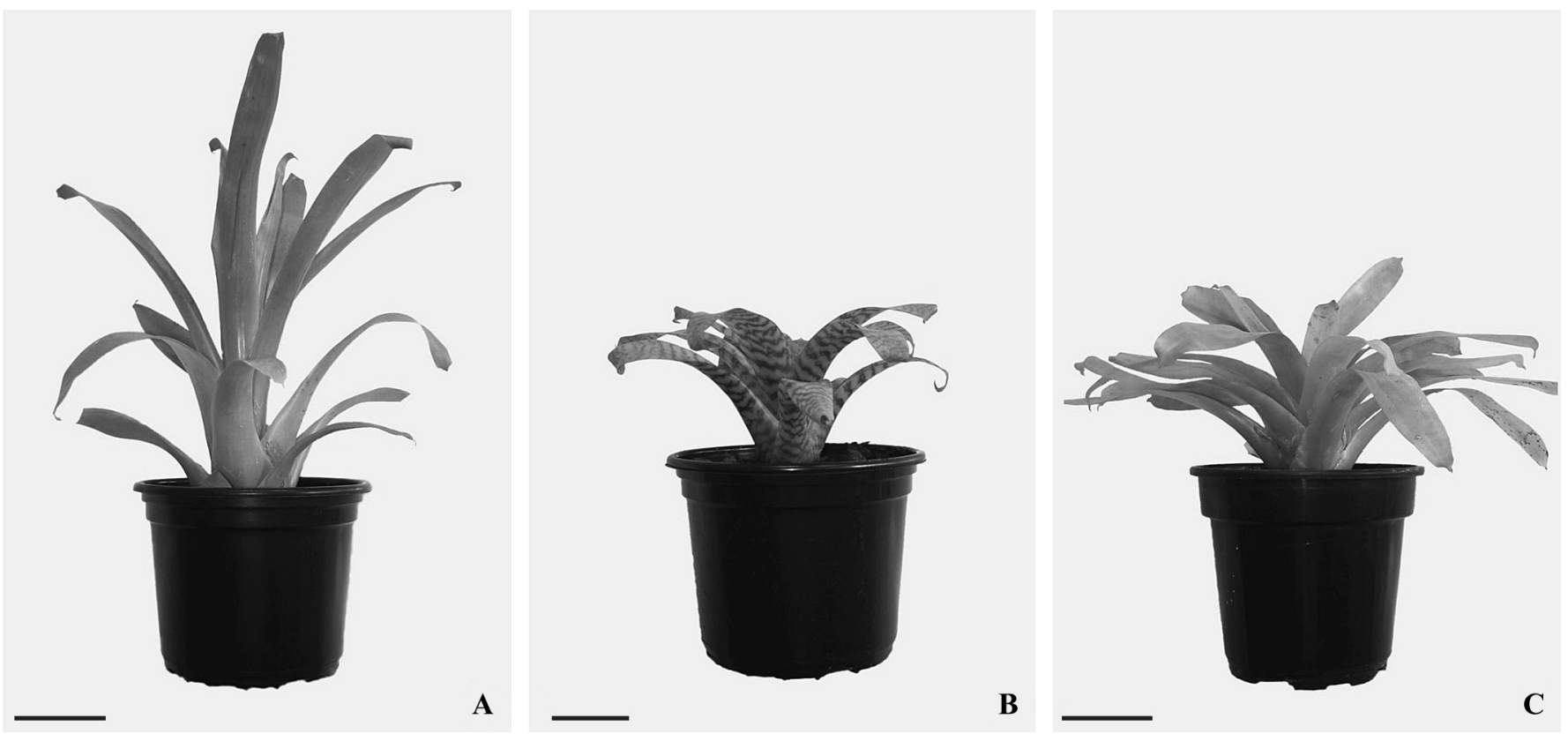

Fig. 1. Two-year-old plants of Vriesea friburguensis Mez, (A), Vriesea hieroglyphica (Carrière) E. Morren (B), and Vriesea unilateralis Mez (C) micropropagated, acclimatized, and cultivated in the greenhouse. Bars $=5 \mathrm{~cm}$.

Slow growth of Vriesea spp. in vitro, when compared with other bromeliads, was readily detected in several experiments in our laboratory. Comparisons of liquid versus solid medium and the use of a temporary immersion system showed very limited increases in Vriesea growth in vitro compared with results observed for Aechmea species, both "tank" epiphyte bromeliads (Aranda-Peres, 2005). The fact that several Vriesea species, endemic to the Brazilian Atlantic Forest, have been listed as species under risk of extinction (Aranda-Peres and Rodriguez, 2006) led us to intensify our efforts to improve their micropropagation. A similar approach successfully used to define a micropropagation medium for passion fruit (Monteiro et al., 2000) was attempted. The approach was to determine the endogenous mineral nutrient composition of micropropagated plants grown in different culture media.

The aim of the present study was to improve the growth and mineral composition of three epiphyte bromeliad species, Vrisea hieroglyhica, $V$. unilateralis, and $V$. friburguensis (Fig. 1), by adjusting the mineral composition of MS medium according to in planta nutrient levels and nutritional recommendations for bromeliads.

\section{Materials and Methods}

Culture media definition. For a preliminary definition of culture media, Aechmea nudicaulis (L.) Griseb, a more abundant and easy-to-propagate bromeliad species, was used. Seeds of $A$. nudicaulis were germinated in vitro on MS medium (Murashige and Skoog, 1962) with the concentration of macronutrients reduced to one-fourth. When seedlings reached $\approx 1 \mathrm{~cm}$ in height, they were transferred into Magenta boxes containing MS medium with the concentration of macro-
Table 1. Nutrient levels in leaves of Aechmea nudicaulis cultivated in vitro in half-strength MS medium and recommendations for Aechmea fasciata obtained from Mills and Jones (1996).

\begin{tabular}{|c|c|c|}
\hline Nutrients & $\begin{array}{l}\text { Aechmea nudicaulis cultivated in } \\
\text { vitro in half-strength MS medium }\end{array}$ & $\begin{array}{l}\text { Recommendations for Aechmea } \\
\text { fasciata (Mills and Jones, 1996) }\end{array}$ \\
\hline & \multicolumn{2}{|c|}{$\left(\mathrm{g} \cdot \mathrm{kg}^{-1}\right)$} \\
\hline $\mathrm{N}$ & 35.70 & $16.20-20.0$ \\
\hline $\mathrm{P}$ & 3.5 & $1.6-7.0$ \\
\hline K & 22.70 & $7.9-30.0$ \\
\hline $\mathrm{Ca}$ & 3.40 & $5.0-19.5$ \\
\hline $\mathrm{Mg}$ & 1.17 & $4.0-8.0$ \\
\hline $\mathrm{S}$ & 1.70 & $1.6-2.5$ \\
\hline \multicolumn{3}{|c|}{$\left(\mathrm{mg} \cdot \mathrm{kg}^{-1}\right)$} \\
\hline $\mathrm{Cu}$ & 4.0 & $6-25$ \\
\hline $\mathrm{Zn}$ & 94.0 & $25-200$ \\
\hline $\mathrm{Mn}$ & 262.0 & $50-300$ \\
\hline B & 29.0 & $25-58$ \\
\hline $\mathrm{Fe}$ & 552.0 & $35-300$ \\
\hline $\mathrm{Cl}$ & 620.0 & - \\
\hline
\end{tabular}

${ }^{\text {} H}$ Half-strength Murashige and Skoog (Murashige and Skoog, 1962) macronutrients and full-strength Murashige and Skoog micronutrients.

Table 2. Culture media defined for in vitro culture of bromeliad species based on MS medium ${ }^{\mathrm{z}}$ and bromeliad in planta mineral nutrient concentrations.

\begin{tabular}{|c|c|c|c|c|}
\hline \multirow[b]{2}{*}{ Mineral salts ${ }^{y}$} & \multicolumn{4}{|c|}{ Culture media } \\
\hline & Half-strength MS & M2 & M3 & M4 \\
\hline Major salts & \multicolumn{4}{|c|}{$\left(\mathrm{mg} \cdot \mathrm{L}^{-1}\right)$} \\
\hline $\mathrm{NH}_{4} \mathrm{NO}_{3}$ & 825 & 704 & 664 & 664 \\
\hline $\mathrm{KNO}_{3}$ & 950 & 950 & 950 & 950 \\
\hline $\mathrm{CaCl}_{2} \cdot 2 \mathrm{H}_{2} \mathrm{O}$ & 220 & 220 & 588 & 1476 \\
\hline $\mathrm{Ca}\left(\mathrm{NO}_{3}\right)_{2} \cdot 4 \mathrm{H}_{2} \mathrm{O}$ & - & 334 & 472 & 472 \\
\hline $\mathrm{MgSO}_{4} \cdot 7 \mathrm{H}_{2} \mathrm{O}$ & 185 & 370 & 370 & 370 \\
\hline $\mathrm{KH}_{2} \mathrm{PO}_{4}$ & 85 & 85 & 85 & 85 \\
\hline $\mathrm{NO}_{3}^{-}: \mathrm{NH}_{4}^{+}$ & $2.0: 1.0$ & $2.4: 1.0$ & $2.2: 1.0$ & $2.2: 1.0$ \\
\hline Minor salts & \multicolumn{4}{|c|}{$\left(\mathrm{mg} \cdot \mathrm{L}^{-1}\right)$} \\
\hline $\mathrm{H}_{3} \mathrm{BO}_{3}$ & 6.2 & 6.2 & 6.2 & 6.2 \\
\hline $\mathrm{MnSO}_{4} \cdot \mathrm{H}_{2} \mathrm{O}$ & 16.9 & 16.9 & 16.9 & 16.9 \\
\hline $\mathrm{ZnSO}_{4} \cdot 7 \mathrm{H}_{2} \mathrm{O}$ & 8.6 & 8.6 & 8.6 & 8.6 \\
\hline $\mathrm{Na}_{2} \mathrm{MoO}_{4} \cdot 2 \mathrm{H}_{2} \mathrm{O}$ & 0.25 & 0.25 & 0.25 & 0.25 \\
\hline $\mathrm{CuSO}_{4} .5 \mathrm{H}_{2} \mathrm{O}$ & 0.025 & 0.05 & 0.05 & 0.05 \\
\hline $\mathrm{CoCl}_{2} \cdot 6 \mathrm{H}_{2} \mathrm{O}$ & 0.025 & 0.025 & 0.025 & 0.025 \\
\hline $\mathrm{FeSO}_{4} \cdot 7 \mathrm{H}_{2} \mathrm{O}$ & 37.3 & 18.65 & 18.65 & 18.65 \\
\hline $\mathrm{Na}_{2}$ EDTA & 27.8 & 13.9 & 13.9 & 13.9 \\
\hline
\end{tabular}

${ }^{\mathrm{z}}$ Half-strength MS = half-strength Murashige and Skoog (Murashige and Skoog, 1962) macronutrients and full-strength Murashige and Skoog micronutrients.

${ }^{y}$ Bold letters denote different amounts of salts among the different media. 
nutrients reduced to half-strength, full-strength MS micronutrients and vitamins, $30 \mathrm{~g} \cdot \mathrm{L}^{-1}$ sucrose, and solidified with phytagel $\left(2 \mathrm{~g} \cdot \mathrm{L}^{-1}\right)$. Every 3 weeks, plantlets were subcultured to fresh medium and after $60 \mathrm{~d}$ in culture, leaf mineral analysis was done according to Malavolta et al. (1992; see leaf mineral analysis subsequently). Nutrient levels were compared with those available in the literature for bromeliads (Mills and Jones, 1996; Table 1).

Based on these observations, and as a result of the importance of calcium $(\mathrm{Ca})$ in so many mechanisms in plant growth and metabolism, the following media were defined varying the $\mathrm{Ca}$ concentration: $1.5 \mathrm{~mm}$ (half-strength MS), $3.0 \mathrm{~mm}$ (M2), $6.0 \mathrm{~mm}$ (M3), and $12.0 \mathrm{~mm}$ (M4), which corresponds to $1 \times, 2 \times, 4 \times$, and $8 \times$ the $\mathrm{Ca}$ concentration in half-strength MS medium (Tables 2 and 3). Additionally, magnesium (Mg) and copper $(\mathrm{Cu})$ concentrations were doubled and iron (Fe) was reduced by half in the new media (Tables 2 and 3). As a consequence of the salts used to increase $\mathrm{Mg}$ and $\mathrm{Cu}$ concentrations, sulfur levels were also increased $(1.69 \times)$. The reduction of the source of $\mathrm{Fe}$ (FeS$\mathrm{O}_{4} .7 \mathrm{H}_{2} \mathrm{O}+\mathrm{Na}_{2}$ EDTA) caused a reduction in sodium concentration. Besides calcium chloride, we also used calcium nitrate, which is not normally present in MS medium, to increase the concentration of $\mathrm{Ca}$. This also increased the level of chlorine in culture media M3 and M4 but maintained the nitrate:ammonium ratio only slightly different in M2 (2.4:1.0), M3 (2.2:1.0), and M4 (2.2:1.0) compared with half-strength MS (2.0:1.0).

In vitro culture of three Vriesea species in the newly defined media. Vriesea friburguensis Mez, V. hieroglyphica (Carrière) E. Morren, and $V$. unilateralis Mez seeds were germinated in vitro on MS medium with the concentration of macronutrients reduced to one-fourth. When plantlets were $\approx 1 \mathrm{~cm}$ in height, they were transferred to Magenta boxes containing MS medium with the concentration of macronutrients reduced to halfstrength and MS micronutrients and vitamins kept at full strength, $30 \mathrm{~g} \cdot \mathrm{L}^{-1}$ sucrose, and solidified with phytagel $\left(2 \mathrm{~g} \cdot \mathrm{L}^{-1}\right)$. Cultures were subcultured every 3 weeks until the seedlings reached $\approx 3 \mathrm{~cm}$ in height with average fresh weight of $0.15 \mathrm{~g}$ ( $V$. friburguensis and $V$. hieroglyphica) and $0.10 \mathrm{~g}$ (V. unilateralis). These plantlets were then selected for the experiment and transferred to the four previously defined culture media: half-strength MS, M2, M3, and M4 (Table 2) supplemented with MS vitamins, $30 \mathrm{~g} \cdot \mathrm{L}^{-1}$ sucrose, $0.5 \mathrm{mg} \cdot \mathrm{L}^{-1} \mathrm{BAP}$, and solidified with phytagel $\left(2 \mathrm{~g} \cdot \mathrm{L}^{-1}\right)$.

A completely randomized $3 \times 4$ factorial design with three species and four culture media with six replications was used. Each replication was composed of one magenta box with six plantlets.

The $\mathrm{pH}$ of all media was adjusted to 5.8 before autoclaving using $\mathrm{HCl}$ and $\mathrm{KOH}$ solutions. All cultures were maintained in a growth room under a 16 -h photoperiod, temperature of $27 \pm 2{ }^{\circ} \mathrm{C}$, and light intensity
Table 3. Concentration of individual nutrients in half-strength $\mathrm{MS}^{\mathrm{z}}$ and media defined for in vitro culture of Vriesea hieroglyphica, $V$. friburguensis, and $V$. unilateralis, based on MS medium and bromeliad in planta mineral nutrient concentrations.

\begin{tabular}{lcccc}
\hline & \multicolumn{4}{c}{ Culture media } \\
\cline { 2 - 5 } Nutrient & Half-strength MS & M2 & M3 & M4 \\
\hline Macronutrients & $\left(\mathrm{mg} \cdot \mathrm{L}^{-1}\right)(\mathrm{mM})$ & & & \\
$\mathrm{N}$ & $419(29.9)$ & $417(29.8)$ & $419(29.9)$ & $419(29.9)$ \\
$\mathrm{P}$ & $19(0.6)$ & $19(0.6)$ & $19(0.6)$ & $19(0.6)$ \\
$\mathrm{K}$ & $390(9.97)$ & $390(9.97)$ & $390(9.97)$ & $390(9.97)$ \\
$\mathbf{C a}$ & $60(1.5)$ & $117(3.0)$ & $238(6.0)$ & $480(12.0)$ \\
$\mathbf{M g}$ & $18(0.74)$ & $36(1.48)$ & $36(1.48)$ & $36(1.48)$ \\
$\mathbf{S}$ & $32(1.02)$ & $54(1.68)$ & $54(1.68)$ & $54(1.68)$ \\
Micronutrients $\left(\mathrm{mg} \cdot \mathrm{L}^{-1}\right)(\mu \mathrm{M})$ & & & $3.730(66.8)$ \\
Fe & $7.471(133)$ & $3.730(66.8)$ & $3.730(66.8)$ & $0.012(0.18)$ \\
$\mathbf{C u}$ & $0.006(0.09)$ & $0.012(0.18)$ & $0.012(0.18)$ & $1.952(29.8)$ \\
$\mathrm{Zn}$ & $1.952(29.8)$ & $1.952(29.8)$ & $1.952(29.8)$ & $5.490(100)$ \\
Mn & $5.490(100)$ & $5.490(100)$ & $5.490(100)$ & $1.078(99.7)$ \\
$\mathrm{B}$ & $1.078(99.7)$ & $1.078(99.7)$ & $1.078(99.7)$ & $355(10,034)$ \\
$\mathbf{C l}$ & $53.0(1,495)$ & $53.0(1,495)$ & $141(3,997)$ & \\
\hline
\end{tabular}

${ }^{\mathrm{z}}$ Half-strength MS = half-strength Murashige and Skoog (Murashige and Skoog, 1962) macronutrients and full-strength Murashige and Skoog micronutrients.

${ }^{y}$ Bold letters denote different amount of nutrients among the different media. Numbers between parentheses denote $\mathrm{mm}$ (macronutrients) or $\mu \mathrm{M}$ (micronutrients) values.
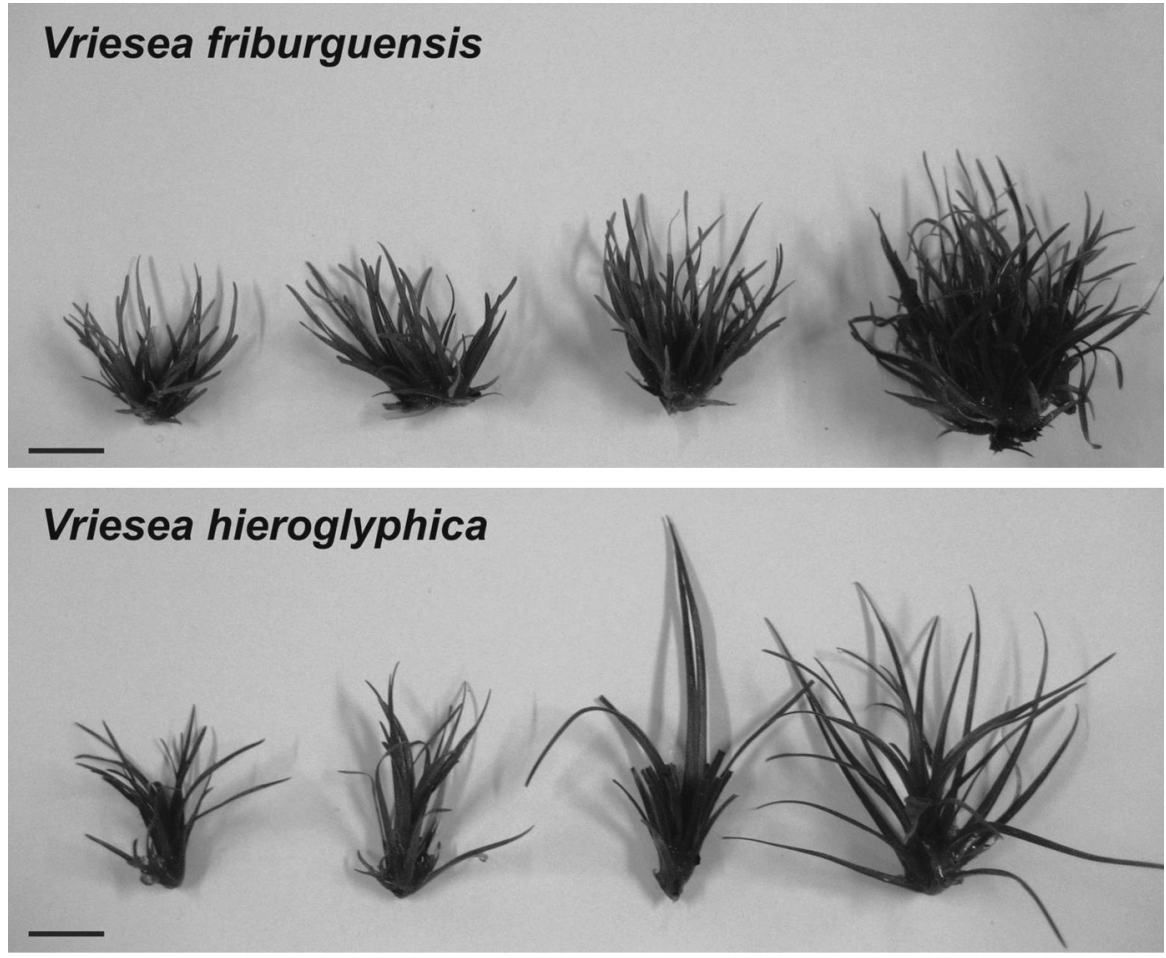

\section{Vriesea unilateralis}

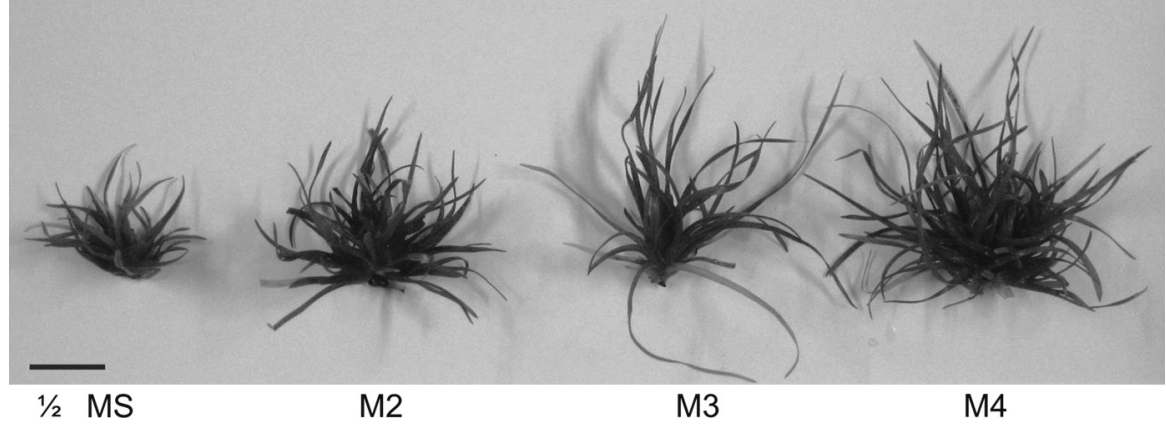

Fig. 2. Representative plantlets of three Vriesea species cultured for 12 weeks with subcultures at 4-week intervals in different culture media (half-strength Murashige and Skoog, M2, M3, or M4 described in Table 2). Bars $=1 \mathrm{~cm}$. 
of $40 \mu \mathrm{mol} \cdot \mathrm{m}^{-2} \cdot \mathrm{s}^{-1}$. Cultures were subcultured every 3 weeks and the experiment was evaluated after 12 weeks through measurements of fresh and dry weight and leaf mineral analysis.

Fresh and dry weight of plantlets grown in vitro. The plantlets were thoroughly washed in tap water followed by the separation of roots from aerial parts. Fresh weight of plantlets from each replication was taken by weighting individual plants and then the samples were dried for $72 \mathrm{~h}$ at $62{ }^{\circ} \mathrm{C}$, when weight stabilized, for dry weight measurement of individual plantlets. For fresh and dry weight determination, an average of 25 plantlets was taken. Means were compared by Tukey test using the Assistat Package (www.assistat.com).

Leaf mineral analysis. The total dried aerial parts of the plantlets were analyzed for the determination of leaf macro and micronutrients using the methodology for mineral analysis described by Malavolta et al. (1992). Briefly, for nitrogen (N) determination, samples were subjected to a sulfuric digestion and analyzed by the micro-Kjeldahl method (Keys, 1938) using a nitrogen distillator (Tecnal TE 036/1, Piracicaba, SP/Brazil). For potassium (K), Ca, Mg, sulfur (S), phosphorous $(\mathrm{P})$, and the micronutrients $\mathrm{Cu}$, manganese (Mn), Fe, and zinc (Zn), samples were subjected to nitric-perchloric digestion. For boron (B), samples were incinerated. After digestion, $\mathrm{Ca}, \mathrm{Mg}, \mathrm{Cu}, \mathrm{Mn}, \mathrm{Fe}$, and $\mathrm{Zn}$ were determined by atomic emission spectrometry (Spectrometer Perkin Elmer 3110, Norwalk, CT). K was determined by flame photometry (Photometer Micronal B262, São Paulo, Brazil). A digital spectrophotometer (Micronal B 34211, São Paulo, Brazil) was used for determination of $S$ by barium turbidimetry and $\mathrm{P}$ and $\mathrm{B}$ by colorimetry. Chloride $(\mathrm{Cl})$ was determined by titration with $\mathrm{AgNO}_{3}(0.05 \mathrm{~N})$ using potassium chromate $(5 \%)$ as an indicator.

\section{Results}

Leaf mineral analysis of Aechmea nudicaulis plantlets cultured in half-strength MS medium (Table 1) suggested that the plantlets were deficient in $\mathrm{Ca}, \mathrm{Mg}$, and $\mathrm{Cu}$ and that the levels of $\mathrm{N}$ and $\mathrm{Fe}$ were above those recommended by Mills and Jones (1996) (Table 1). Comparisons of the leaf nutrient levels of Aechmea nudicaulis in half-strength MS medium with the recommendations for Aechmea fasciata (Mills and Jones, 1996) and adequations of the medium components resulted in three newly defined media (Tables 2 and 3). These new media were used for culturing the three Vriesea species, which were the object of this work. Levels of the macronutrients $\mathrm{Ca}, \mathrm{Mg}$, and $\mathrm{S}$ and micronutrients $\mathrm{Fe}, \mathrm{Cu}$, and $\mathrm{Cl}$ varied between the evaluated media (Table 3). Visual observations of Vriesea plantlets after 12 weeks of in vitro culture show that all three species $(V$. friburguensis, $V$. unilateralis, $V$. hieroglyphica) cultured on medium containing the highest level of Ca (M4) had enhanced plantlet
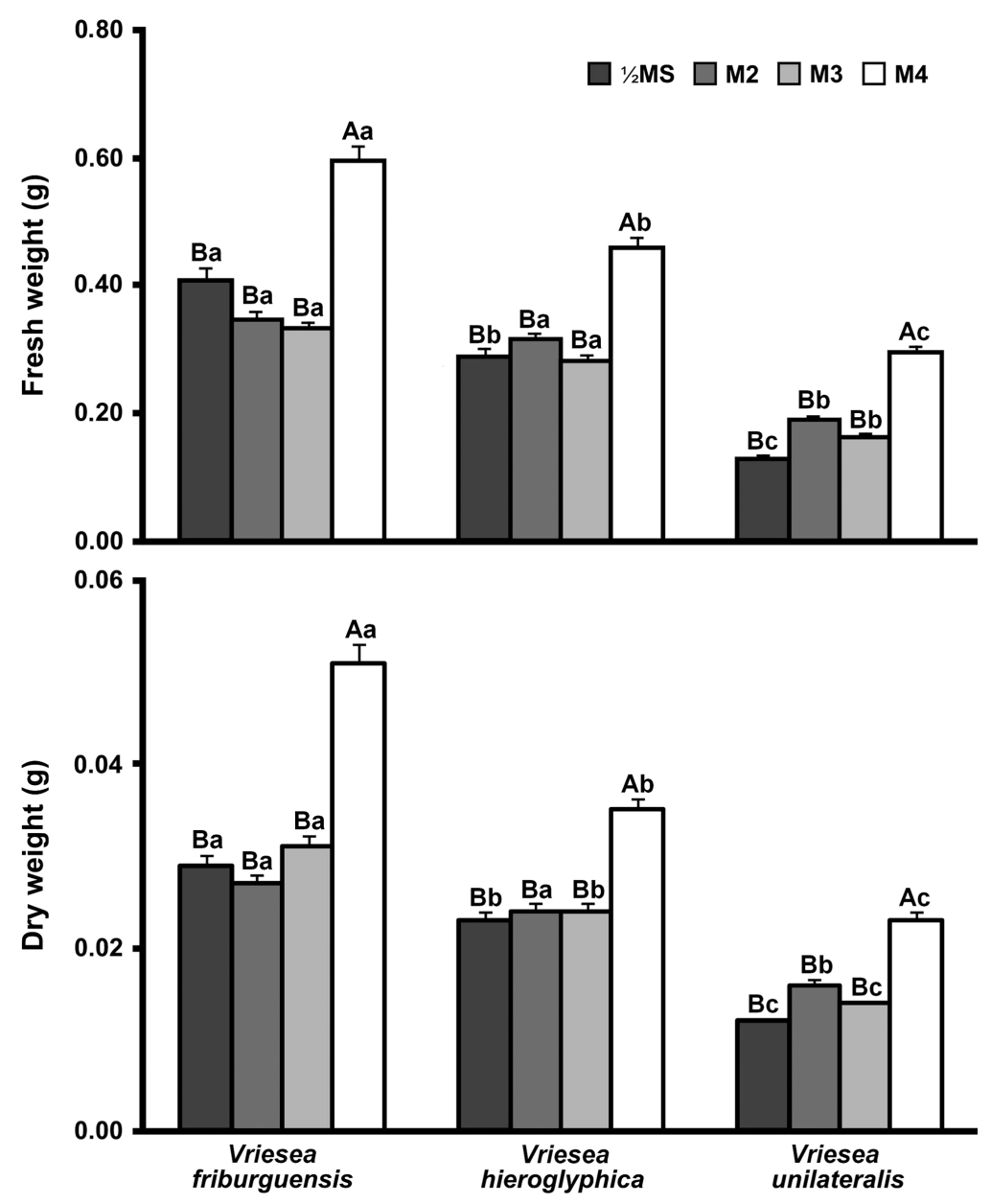

Fig. 3. Fresh and dry weight of plantlets of three Vriesea species cultured on media varying in chemical composition (see Tables 2 and 3). Uppercase and lowercase letters indicate mean comparison among culture media and species, respectively, according to Tukey's test $(P=0.05)$. Bars represent the SE $(\mathrm{n}=25)$.

growth compared with half-strength MS, M2, and M3 media (Fig. 2).

Fresh and dry weight of all three species showed similar results when grown on halfstrength MS, M2, and M3 media (Fig. 3). However, plantlets of all three species grown in M4 medium exhibited significantly $(P<$ $0.05)$ higher fresh and dry weight (Fig. 3). $V$. friburguensis showed the highest growth, especially in M4 medium. However, V. unilateralis showed the highest increase in dry weight when plantlets cultured in halfstrength MS versus M4 were compared with increase in dry weights of $92 \%, 76 \%$, and $52 \%$ observed for $V$. unilateralis, $V$. friburguensis, and $V$. hieroglyphica, respectively. This indicates that although $V$. unilateralis had lower growth rates, this species benefited the most from the nutrient composition changes from half-strength MS to M4.

Macro- (Fig. 4) and micro- (Fig. 5) nutrient concentrations in leaves of plantlets growing on M4 medium were very similar for all three species and presented striking differences when compared with those on halfstrength MS medium. Higher levels of nutrients were observed in plants grown on M4 (Figs. 4 and 5), including some nutrients supplied equally in both media such as $\mathrm{N}$, $\mathrm{K}, \mathrm{Zn}, \mathrm{Mn}$, and B (see Table 3). The only tion among the three species was $\mathrm{P}$, which was supplied in the same amount in halfstrength MS and M4 media yet had foliar concentrations higher on half-strength MS medium for $V$. friburguensis, higher on M4 medium for $V$. unilateralis, and to a lesser extent for $V$. hieroglyphica. For the macronutrients $\mathrm{Ca}, \mathrm{Mg}$, and $\mathrm{S}$, and the micronutrient $\mathrm{Cu}$, which were higher on plantlets cultivated on M4 medium than on halfstrength MS (Table 3), the differences in concentration in leaf tissues in the three species (Figs. 4 and 5) tended to be proportional to the differences in the supplement between the two media. Exceptions are $\mathrm{Cl}$ and $\mathrm{Fe}$. Although the supplement of $\mathrm{Cl}$ in $\mathrm{M} 4$ was 6.7 times greater than that in halfstrength MS, the difference in tissue concentration did not exceed 2.5 times in any of the three species (Fig. 5). This is consistent with the negative electrochemical gradient of plant cells (Higinbotham et al., 1967), which usually hampers the absorption of anions such as $\mathrm{Cl}^{-}$. $\mathrm{Fe}$ concentration in tissues was also not proportional to the quantity added in the medium. In half-strength MS medium, Fe supply was twice as much as in M4 (Table 3); however, Fe concentration in tissues cultured on the two media tended to be similar for all nutrient showing a discrepancy in concentra- 

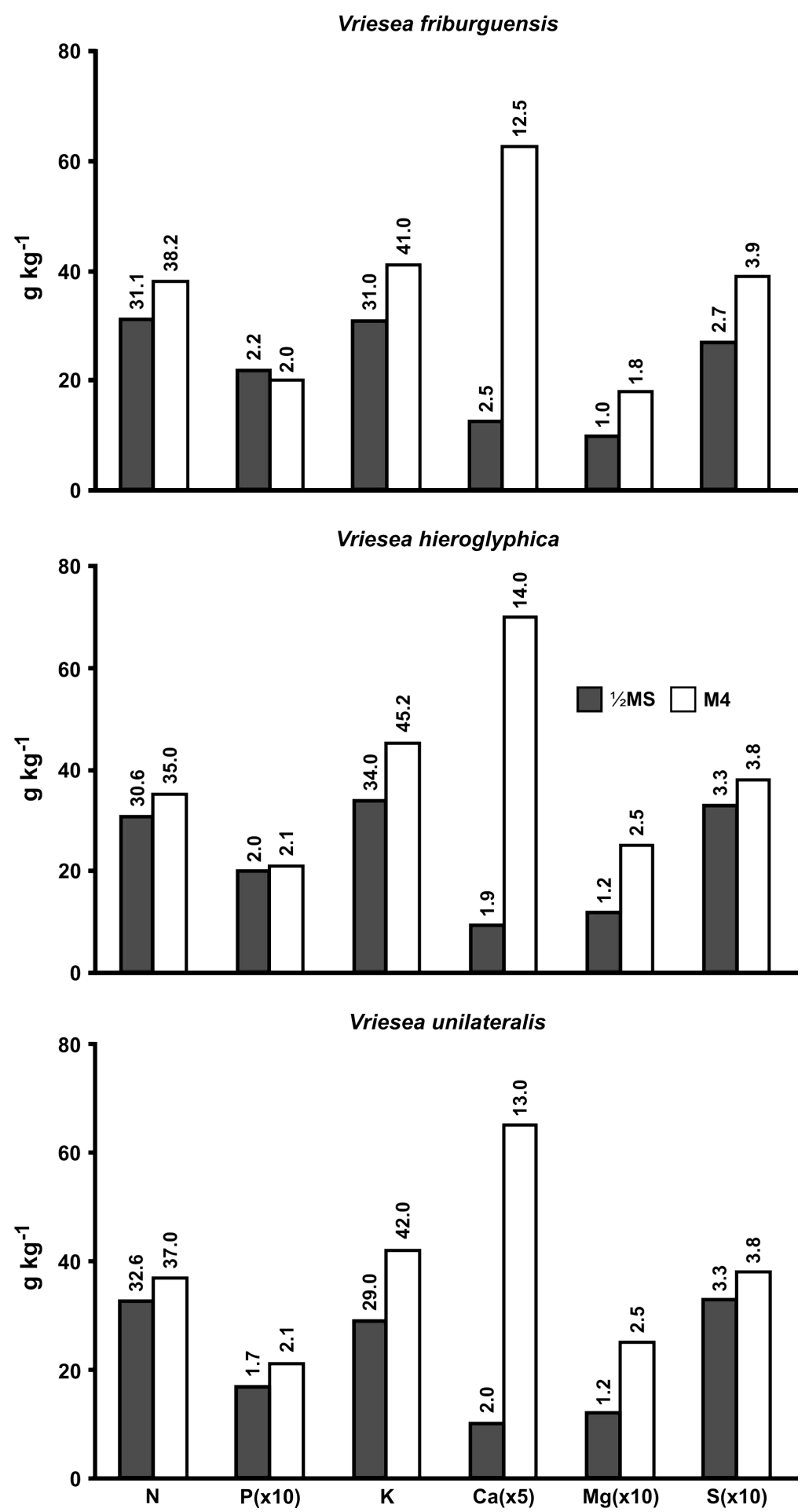

Fig. 4. Macronutrient concentrations in leaves of plantlets of three Vriesea species cultured on media varying in chemical composition (see Tables 2 and 3). Phosphorus, magnesium, and sulfur values were multiplied by 10 and calcium values multiplied by 5 . The numbers above bars represent the original values.

three species (Fig. 5). Moreover, the concentration of both $\mathrm{Fe}$ and $\mathrm{Cl}$ in tissues grown in M4 and half-strength MS was apparently excessive, although no obvious symptoms of toxicity were observed in any of the three species studied (Fig. 2).

\section{Discussion}

In the present work, a similar methodology to that used for passionfruit (Monteiro et al., 2000) was used to design a more adequate medium for the in vitro culture of bromeliads. This was based on the fact that bromeliads present considerable particularities in terms of mineral nutrition in nature (Benzing, 1973), which can affect their behavior in vitro.

The mineral analysis of Aechmea nudicaulis, cultivated on half-strength MS medium (Table 1), suggested the need for a finer adjustment of some of the minerals in the culture medium, especially Ca. Vriesea plantlets grown on M4 medium, had fresh and dry weights significantly superior to those in all media tested and only differed from M2 and M3 in the levels of $\mathrm{Ca}$ and $\mathrm{Cl}$ (see Table 3). Thus, we suggest that the effect of M4 on biomass accumulation (Fig. 3) can be attributed to these two nutrients. Considering that $\mathrm{Cl}$ is a micronutrient, and thus not expected to be needed in high levels, it is very reasonable to assume that the growthpromoting effect of M4 medium was the result of an extra supplement of the macronutrient $\mathrm{Ca}$. In fact, this nutrient accumulated in all three Vriesea species in ranges close to those recommended for another tank bromeliad (Mills and Jones, 1996; see Table 1) only when cultured on medium M4 (12.5 to 14.0 $\mathrm{g} \cdot \mathrm{kg}^{-1}$; see Fig. 4) with accumulation in halfstrength MS (1.9 to $2.5 \mathrm{~g} \cdot \mathrm{kg}^{-1}$ ) even lower than that found in naturally occurring conditions for other tank bromeliads (Benzing, 1973).

The higher levels of $\mathrm{Ca}$ in M4 not only allowed an enhanced growth in all three species of Vriesea (Fig. 2), but also indicate that $\mathrm{Ca}$ may have facilitated the absorption of other nutrients. This seems to be the case for $\mathrm{N}, \mathrm{K}, \mathrm{Zn}, \mathrm{Mn}$, and $\mathrm{B}$ in that the concentration of the nutrients was not increased in the M4 medium composition (Table 3 ) but was present in higher levels in plantlets grown on M4 versus half-strength MS medium (Figs. 4 and 5). A positive effect of $\mathrm{Ca}$ supplementation on N, Zn, Mn, and B accumulation but hardly any change in the concentrations of $\mathrm{K}$ was reported for tobacco (Lopez-Lefebre et al., 2001).

Calcium has an important role in cell signaling (Reddy, 2001) acting as a secondary messenger together with signal transduction proteins such as calmodulin and $\mathrm{Ca}^{2+}$-dependent protein kinases and also maintains the integrity of the plasmalemma. $\mathrm{Ca}^{2+}$ stabilizes cell membranes by connecting various proteins and lipids on membrane surfaces (Hirschi, 2004). This integrity of the plasmalemma leads to a greater turgor pressure (higher water content) and nutrient retention in cells (Fenn and Feagley, 1999). To protect the plasma membrane, $\mathrm{Ca}^{2+}$ must always be present in the external solution (apoplast), where it can regulate the selectivity of ion uptake. Thus, both effects of $\mathrm{Ca}$ in the protection of cell membranes (e.g., regulation of ion uptake and nutrient retention in cells) may account for the enhanced foliar concentration of different nutrients observed when plants are grown in media with higher Ca levels (Figs. 4 and 5). Furthermore, Ca can also directly influence the content of other nutrients acting as a secondary messenger. For instance, it is known that the opening of potassium channels in leaves, especially in guard cells, is affected by $\mathrm{Ca}^{2+}$ as a secondary messenger (Schroeder et al., 2001).

The enhanced growth of bromeliads in M4 medium can be the result of a better nutritional status related to the accumulation of various minerals favored by $\mathrm{Ca}$ as discussed previously. However, an additional 

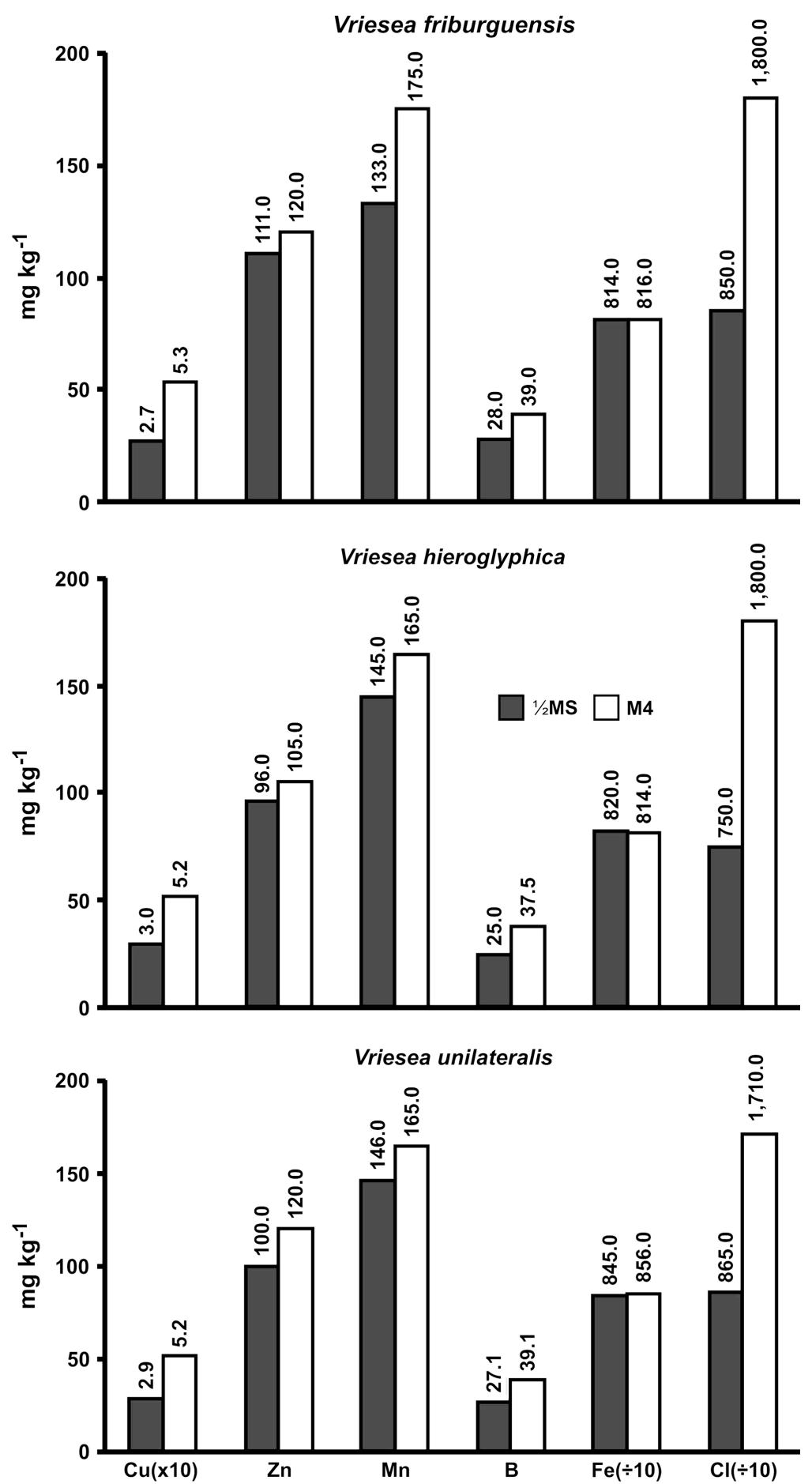

Fig. 5. Micronutrient concentrations in leaves of in vitro cultivated plantlets of three Vriesea species cultured in two different culture media varying in chemical composition (see Tables 2 and 3 ). Copper values were multiplied by 10 and iron and chloride values divided by 10 . The numbers above bars represent the original values.

cause may be the direct effect of $\mathrm{Ca}$ on cell and organ growth. $\mathrm{Ca}$ is involved in cell elongation and cell division, influences cellular $\mathrm{pH}$, and also acts as a regulatory ion in the source-sink translocation of carbohydrates through its effects in cells and cell walls (Hirschi, 2004). Furthermore, plants need $\mathrm{Ca}^{2+}$ to strengthen cell walls and provide biotic and abiotic stress protection. This last effect of $\mathrm{Ca}$ may have had limited importance for the in vitro growth but may have favored plantlets propagated in M4 medium during acclimatization and further ex vitro growth.

When the recommended levels in the literature are considered (Mills and Jones, 1996), some elements such as $\mathrm{Mg}$ and $\mathrm{Cu}$ were still in low concentration, whereas an apparent excess of $\mathrm{Fe}$ and $\mathrm{N}$ was detected in the leaves of plants cultured on M4 medium. Although the results in terms of growth were considerably positive, fine adjustments to the medium can be further attempted to improve culture conditions. Studies on the interaction between mineral elements and growth regulators such as cytokinins should also be attempted, because it is known that this class of substances may act as a negative signal to some nutrient starvation in plants (Martin et al., 2000).

The present work has shown the importance of making adjustments to the mineral composition of the culture medium, which resulted in higher levels of mineral elements in plantlets and improved growth during the micropropagation process of three Vriesea species. Particular changes were related to the calcium levels in the culture medium; however, other elements that were not present in the recommended levels were also adjusted.

\section{Literature Cited}

Alves, G.M., L.L. Dal Vesco, and M.P. Guerra 2006. Micropropagation of the Brazilian endemic bromeliad Vriesea reitzii through nodule clusters culture. Scientia Hort. 110:204-207.

Aranda-Peres, A.N. 2005. Cultivo in vitro de bromélias da Mata Atlântica: Micropropagação, avaliação nutricional e substratos para aclimatação, Centro de Energia Nuclear na Agricultura, Universidade de São Paulo, PhD Diss.

Aranda-Peres, A.N. and A.P.M. Rodriguez. 2006. Bromeliads, p. 644-655. In: da Silva, J.A. (ed.) Floriculture, ornamental and plant biotechnology. Vol IV. Global Science Books, London, UK.

Benzing, D. 1973. Mineral nutrition and related phenomena in Bromeliaceae and Orchidaceae. Q. Rev. Biol. 48:277-290.

Benzing, D. 1990. Vascular epiphytes. Cambridge University Press, Cambridge, UK.

Carneiro, L.A., R.F. Araújo, and C.J. Brito. 1999 In vitro regeneration from leaf explants of Noeregelia cruenta (R. Graham). Plant Cell Tissue Organ Cult. 55:79-83.

Carneiro, L.A., M.S. Candido, R.F. Araújo, M.H Fonseca, O.J. Crocomo, and E. Mansur. 1998. Clonal propagation of Cryptanthus sinuosus L.B. Smith, an endemic stoloniferous Bromeliaceae species from Rio de Janeiro, Brazil. Plant Tiss. Cult. Biotech. 4:152-158.

Cozza, R., D. Turco, C.B. Bati, and M.B. Bitonti. 1997. Influence of growth medium on mineral composition and leaf histology in micropropagated plantlets of Olea europaea. Plant Cell Tissue Organ Cult. 51:215-223.

Crayn, D.M., K. Winter, and A.C. Smith. 2004. Multiple origins of crassulacean acid metabolism and the epiphytic habit in the Neotropical family Bromeliaceae. Proc. Natl. Acad. Sci. USA 1001:3703-3708.

Cushman, J.C. and H.J. Bohnert. 1999. Crassulacean acid metabolism: Molecular genetics. Annu. Rev. Plant Physiol. Plant Mol. Biol. 50:305-332.

Endres, L. and H. Mercier. 2001. Ammonium and urea as nitrogen sources for bromeliads. J. Plant Physiol. 158:205-212.

Fenn, L.B. and S. Feagley. 1999. Review of beneficial uses of calcium and ammonium salts for stimulating plant growth and metabolite translocation. Commun. Soil Sci. Plant Anal. 30:2627-2641.

Gonçalves, S., P.J. Correia, M.A. Martins-Loução, and A. Romano. 2005. A new formulation for in vitro rooting of carob tree based on leaf 
macronutrients concentrations. Biol. Plant. 49:277-280.

Gribble, K., J.P. Conroy, P. Holford, and J.P. Milhan. 2002. In vitro uptake of minerals by Gypsophila paniculata and hybrid eucalypts, and relevance to media mineral formulation. Aust. J. Bot. 50:713-723.

Higinbotham, N., B. Etherton, and R.J. Foster. 1967. Mineral ion contents and cell transmembrane electropotentials of pea and oat seedling tissue. Plant Physiol. 42:37-46.

Hirschi, K.D. 2004. The calcium conundrum. Both versatile nutrient and specific signal. Plant Physiol. 136:2438-2442.

Hosoki, T. and T. Asahira. 1980. In vitro propagation of bromelias in liquid culture. HortScience 5:603-604.

Keys, A. 1938. A rapid micro-Kjeldahl method. J. Biol. Chem. 132:181-187.

Lin, C.Y. and D.M. Yeh. 2008. Potassium nutrition affects leaf growth, anatomy, and macroelements of Guzmania. HortScience 43:146148.

Lopez-Lefebre, L.R., R.M. Rivero, P.C. Garcia, E. Sanchez, J.M. Ruiz, and L. Romero. 2001. Effect of calcium on mineral nutrient uptake and growth of tobacco. J. Sci. Food Agr. 81:1334-1338.

Malavolta, E., G.C Vitti, and A.S. Oliveira. 1992. Avaliação do estado nutricional das plantas: Princípios e aplicações. 2nd Ed. Associação Brasileira para Pesquisa da Potassa e do Fosfato, Piracicaba.

Martin, A.C., J.C. Del Pozzo, J. Iglesias, V. Rubio, R. Solano, A. De la Peña, A. Leyva, and J. PazAres. 2000. Influence of cytokinins on the expression of phosphate starvation responsive genes in Arabidopsis. Plant J. 34:558-567.
Mathew, V.H. and P.S. Rao. 1982. In vitro plant regeneration in lateral bud explants of Cryptanthus bromelioides var. Tricolor M.B. Plant Cell Rep. 1:108-110.

Mercier, H. and G. Kerbauy. 1992. In vitro multiplication of Vriesea foresteriana. Plant Cell Tissue Organ Cult. 30:247-249.

Mills, H.A. and J.B. Jones, Jr. 1996. Plant analysis handbook. II-A practical sampling, preparation, analysis, and interpretation guide. MicroMacro Publishing, Athens, GA.

Monteiro, A.C.B., E.N. Higashi, A.N. Gonçalves, and A.P.M. Rodriguez. 2000. A novel approach for the definition of the organic medium components for micropropagation of yellow passionfruit (Passiflora edulis Sims. f. flavicarpa Deg.). In Vitro Cell. Dev. Biol. Plant 36:527531.

Morard, P. and M. Henry. 1998. Optimization of the mineral composition of in vitro culture medium. J. Plant Nutr. 21:1565-1576.

Murashige, T. and F. Skoog. 1962. A revised medium for rapid growth and bioassays with tobacco tissue cultures. Physiol. Plant. 15:473497.

Nas, M.N. and P.E. Read. 2004. A hypothesis for the development of a defined tissue culture medium of higher plants and micropropagation of hazelnuts. Scientia Hort. 101:189-200.

Niedz, R.P. and T.J. Evens. 2007. Regulation of plant tissue growth by mineral nutrition. In Vitro Cell. Dev. Biol. Plant 43:370-381.

Nievola, C.C., H. Mercier, and N. Majerowicz. 2001. Levels of nitrogen assimilation in bromeliads with different growth habits. J. Plant Nutr. 24:1387-1398.

Pickens, K.A., J.M. Affolter, H.Y. Wetzstein, and J.H.D. Wolf. 2003. Enhanced seed germination and seedling growth of Tillandsia eizii in vitro. HortScience 38:101-104.

Pickens, K.A., J. Wolf, J.M. Affolter, and H.Y. Wetzstein. 2000. In Vitro propagation of the ornamental bromeliad, Tillandsia eizii. HortScience 35:447.

Pickens, K.A., J. Wolf, J.M. Affoler, and H. Wetzstein. 2006. Adventitious bud development and regeneration in Tillandsia eizii. In Vitro Cell. Dev. Biol. Plant 42:348-353.

Pompelli, M.F. and M.P. Guerra. 2005. Micropropagation enables the mass propagation and conservation of Dyckia distachya Hassler. Crop Breed. Appl. Biotechnol. 5:117-126.

Rech Filho, A., L.L. Dal Vesco, R.O. Nodari, R.W. Liscka, C.V. Müller, and M.P. Guerra. 2005. Tissue culture for the conservation and mass propagation of Vriesea reitzii Leme and Costa, a bromeliad threatened of extinction from the Brazilian Atlantic Forest. Biodivers. Conserv. 8:1799-1808.

Reddy, A.S.N. 2001. Calcium: Silver bullet in signaling. Plant Sci. 161:381-404.

Schroeder, J.I., G. Allen, V. Hugouvieux, J.M. Kwak, and D. Waner. 2001. Guard cell signal transduction. Annu. Rev. Plant Physiol. Plant Mol. Biol. 52:627-658.

Sotiropoulos, T.E. 2007. Effect of $\mathrm{NaCl}$ and $\mathrm{CaCl}_{2}$ on growth and content of minerals, chlorophyll, proline and sugars in the apple rootstock M4 cultured in vitro. Biol. Plant. 51:177180.

Sotiropoulos, T.E., S. Fotopoulos, K.N. Dimassi, V. Tsirakoglou, and I.N. Therios. 2006. Response of the pear rootstock to boron and salinity in vitro. Biol. Plant. 50:779-781.

Williams, R.R. 1991. Factors determining mineral uptake in vitro. Acta Hort. 289:165-169. 